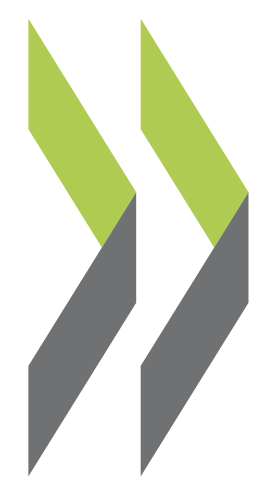

OECD Economics Department Working Papers No. 1498

Euro Area unemployment insurance at the time of zero nominal interest rates

Guillaume Claveres, Jan Stráský 


\section{Unclassified}

ECO/WKP(2018)46

Organisation de Coopération et de Développement Économiques

Organisation for Economic Co-operation and Development

30-Jul-2018

ECONOMICS DEPARTMENT

English - Or. English

EURO AREA UNEMPLOYMENT INSURANCE AT THE TIME OF ZERO NOMINAL INTEREST RATES

ECONOMICS DEPARTMENT WORKING PAPERS No. 1498

By Guillaume Claveres and Jan Stráský

OECD Working Papers should not be reported as representing the official views of the OECD or of its member countries. The opinions expressed and arguments employed are those of the author(s).

Authorised for publication by Isabell Koske, Deputy Director, Country Studies Branch, Economics Department.

All Economics Department Working Papers are available at www.oecd.org/eco/workingpapers

JT03434819

This document, as well as any data and map included herein, are without prejudice to the status of or sovereignty over any territory, to the delimitation of international frontiers and boundaries and to the name of any territory, city or area. 
OECD Working Papers should not be reported as representing the official views of the OECD or of its member countries. The opinions expressed and arguments employed are those of the author(s).

Working Papers describe preliminary results or research in progress by the author(s) and are published to stimulate discussion on a broad range of issues on which the OECD works.

Comments on Working Papers are welcomed, and may be sent to OECD Economics Department, 2 rue André Pascal, 75775 Paris Cedex 16, France, or by e-mail to eco.contact@oecd.org.

All Economics Department Working Papers are available at www.oecd.org/eco/workingpapers.

This document and any map included herein are without prejudice to the status of or sovereignty over any territory, to the delimitation of international frontiers and boundaries and to the name of any territory, city or area.

The statistical data for Israel are supplied by and under the responsibility of the relevant Israeli authorities. The use of such data by the OECD is without prejudice to the status of the Golan Heights, East Jerusalem and Israeli settlements in the West Bank under the terms of international law.

On 3 May 2018, the OECD Council invited Lithuania to become a Member. At the time of preparation the deposit of Lithuania's instrument of accession to the OECD Convention was pending and therefore Lithuania does not appear in the list of OECD Members and is not included in the OECD zone aggregates.

On 25 May 2018, the OECD Council invited Colombia to become a Member. At the time of preparation the deposit of Colombia's instrument of accession to the OECD Convention was pending and therefore Colombia does not appear in the list of OECD Members and is not included in the OECD zone aggregates.

\section{(c) OECD (2018)}

You can copy, download or print OECD content for your own use, and you can include excerpts from OECD publications, databases and multimedia products in your own documents, presentations, blogs, websites and teaching materials, provided that suitable acknowledgment of OECD as source and copyright owner is given. All requests for commercial use and translation rights should be submitted to rights@oecd.org 
ECO/WKP(2018)46

\section{ABSTRACT/RÉSUMÉ \\ Euro Area unemployment insurance at the time of zero nominal interest rates}

The discussion about a fiscal stabilisation capacity as a way of providing more fiscal integration in the euro area has strengthened in the aftermath of the European sovereign debt crisis. Among the instruments that can be used for temporary macroeconomic stabilisation in the presence of both asymmetric and area-wide shocks, a euro area unemployment insurance scheme has attracted increased attention. We build a two-region DSGE model with supply, demand and labour market frictions and introduce in it an area-wide unemployment insurance scheme that is entitled to borrow in financial markets. The model is calibrated to the euro area core and periphery data. For a country-specific negative demand shock hitting the periphery, we find the scheme to reduce the drop in Periphery output by about one fifth and the drop in union output by about a third. The scheme is effective when some households are cut from financial markets, and even more so when the national government also loses market access.

This Working Paper relates to the 2018 OECD Economic Survey of the Euro Area (http://www.oecd.org/eco/surveys/economic-survey-european-union-and-euro-area.htm) JEL classification: E32, E52, E63, J65

Keywords: Unemployment insurance, search and matching, zero lower bound, fiscal union

$* * * * * * * * * *$

\section{L'assurance chômage dans la zone euro dans le contexte de taux d'intérêt nominaux zéro}

Les discussions portant sur une capacité de stabilisation budgétaire comme moyen de renforcer l'intégration budgétaire dans la zone euro se sont intensifiées au lendemain de la crise européenne de la dette souveraine. Parmi les instruments pouvant être utilisés pour induire une stabilisation macroéconomique temporaire face à des chocs à la fois asymétriques et à l'échelle de la zone euro, le régime d'assurance chômage attire une attention croissante. Nous avons établi un modèle d'équilibre général stochastique dynamique sur deux régions, intégrant des frictions au niveau de l'offre, de la demande et du marché du travail, et nous y avons introduit un régime d'assurance chômage conçu à l'échelle de la zone et autorisé à emprunter sur les marchés de capitaux. Le modèle a été calibré à partir des données relatives au cœur et à la périphérie de la zone euro. En cas de choc négatif affectant la demande dans un pays particulier de la périphérie, on constate que le régime permet de réduire la baisse de la production de la périphérie d'environ un cinquième et la baisse de la production de l'Union d'environ un tiers. Ce régime est efficace si certains ménages sont isolés des marchés de capitaux, et il l'est d'autant plus si les pouvoirs publics nationaux le sont aussi.

Ce Document de travail se rapporte à l'Étude économique de l'OCDE de la Zone Euro, 2018 (http://www.oecd.org/fr/eco/etudes/etude-economique-union-europeenne-et-zone-euro.htm) JEL classification: E32, E52, E63, J65

Mots clefs: assurance chômage, frictions sur le marché de l'emploi, politique monétaire à taux zéro, union fiscale. 


\section{TABLE OF CONTENTS}

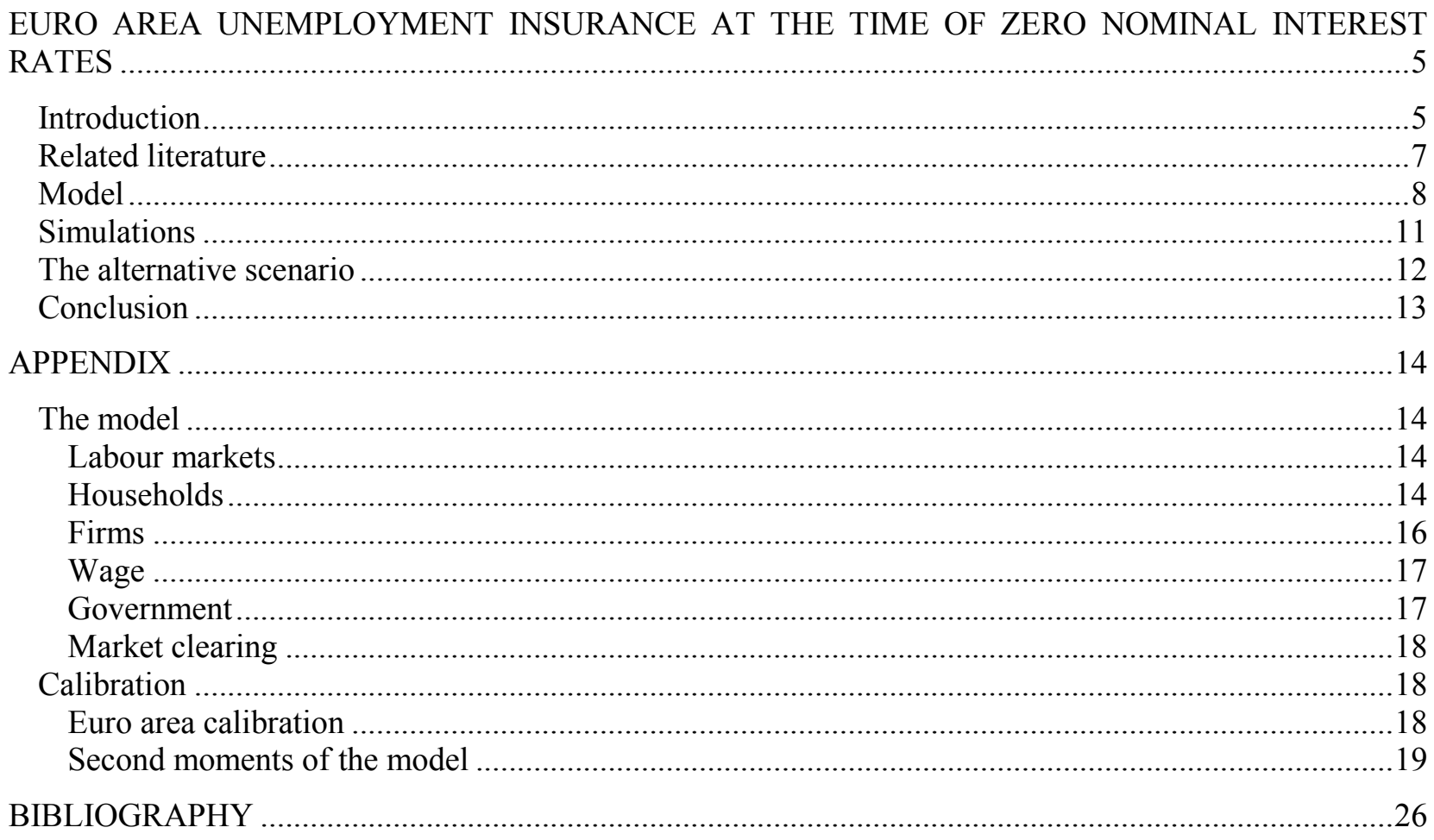

\section{Tables}

1. Second moments of the model compared to the data

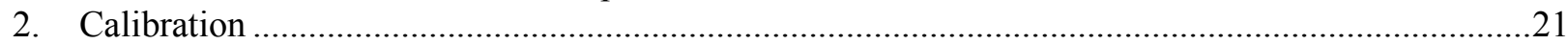

\section{Figures}

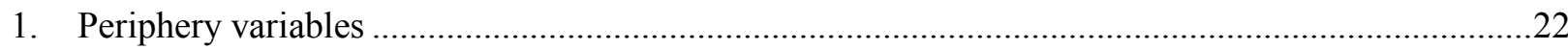

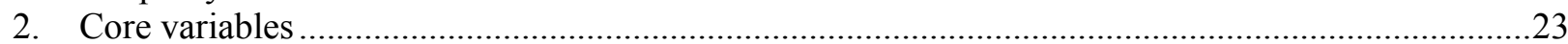

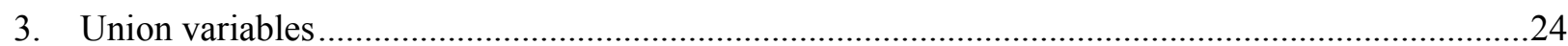

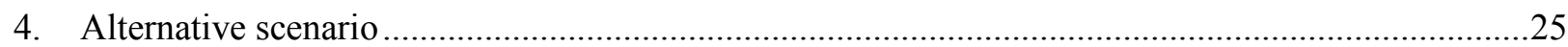


ECO/WKP(2018)46

\title{
EURO AREA UNEMPLOYMENT INSURANCE AT THE TIME OF ZERO NOMINAL INTEREST RATES
}

\author{
Guillaume Claveres and Jan Stráský ${ }^{1}$
}

\section{Introduction}

1. The euro area sovereign debt crisis has exposed important gaps in the architecture of the Economic and Monetary Union. The introduction of the euro did not lead to moderation of countryspecific shocks and national fiscal policies in many countries remained excessively pro-cyclical, not providing sufficient fiscal buffers against country-specific shocks. In addition, the doom-loop between banks and their sovereigns, together with strong financial linkages across countries, allowed countryspecific shocks to turn into systemic ones. Considerable cross-country spill-overs and contagion from country-specific shocks and policies underlined the lack of sufficient risk-sharing mechanisms, both private and public, in the euro area.

2. In a monetary union where member countries give up independent monetary policy and irrevocably fix the nominal exchange rates vis-à-vis the other members, macroeconomic adjustment toolkit shrinks and other channels to mitigate crises become necessary to replace the missing policy instruments. Since the cross-border labour mobility remains low, private risk sharing in Europe usually takes place through cross-border flows of capital and credit. International capital flows lead to more geographically diversified portfolios that are less correlated with domestic income, while cross-border credit flows facilitate consumption smoothing in the aftermath of a country-specific shock. Despite recent progress with the banking and capital markets unions, financial intermediation in Europe is primarily bank based and financial markets remain fragmented along national lines. As a result of this fragmentation, the level of private risk-sharing compared to federations like the United States, Canada or Germany tends to be considerably lower and biased towards domestic credit, rather than capital flows (Allard et al., 2013). Moreover, the risk sharing through the bank lending channel tends to break down in period of crisis, exactly when needed the most (Furceri and Zdzienicka, 2015).

3. Public risk sharing, which usually takes place through taxes and transfers, is virtually nonexistent at the euro area and the EU level. Federal states typically allocate significant resources at the federal level, with regional spending just below $50 \%$ of the total (and some $75 \%$ in Canada). In comparison, the EU budget represents some $2 \%$ of member states total expenditure, while the ESM's lending capacity of EUR 500 billion represents about $10 \%$ of the euro area countries' combined budgets. These tools are much smaller than usual in federations and neither of them is specifically meant for macroeconomic stabilisation.

\footnotetext{
${ }^{1}$ Jan Stráský is Economist at the European Union/Euro Area desk in the Country Studies Branch of the OECD Economics Department (Jan.STRASKY@oecd.org). At the time of writing, Guillaume Claveres was Junior Economist at the European Union/Euro Area desk in the Country Studies Branch of the OECD Economics Department. The authors would like to thank, without implicating, Pierre Beynet, Filippo Gori and Oliver Roehn of the OECD, Agnès Bénassy-Quéré (Paris School of Economics) as well as the participants of the $1^{\text {st }}$ CESifo EconPol Europe PhD Workshop in Munich, the $20^{\text {th }}$ Banca d'Italia Workshop on Public Finances in Rome, the 2018 French Economic Association conference in Paris and the 2018 Computation in Economics and Finance conference in Milan, for useful suggestions and comments on earlier versions of this paper. The authors are also grateful to Elisabetta Pilati for editorial assistance. All remaining errors are ours.
} 
4. At the European level, a common fiscal stabilisation capacity may address both asymmetric and area-wide shocks. For country-specific shocks, the national budget stabilisers may be constrained by the lack of fiscal space or high marginal borrowing costs. Although area-wide shocks could, in principle, be stabilised through a more accommodative monetary policy stance, monetary policy can usefully be complemented by fiscal policy, especially at the zero-lower bound. Moreover, weak economic growth in the euro area and especially the weak inflation suggests that nominal interest rates may stay close to zero for a prolonged period of time. Similarly, the global neutral rate may remain low, perhaps around $1 \%$, in the medium to long term, reflecting wide-ranging shifts in saving and investment preferences, and making monetary policy more frequently constrained by the zero lower bound (Rachel and Smith, 2017).

5. The idea of complementing the monetary union in Europe with some form of fiscal federalism can be traced back to the MacDougall Report suggesting a community budget of 2-2.5\% of GDP and other measures, including a common unemployment fund going a small part of the way towards creating a situation in which the monetary union could be sustained (MacDougall (1977), p.13). More recently, the Five Presidents Report highlighted the key characteristics for such a scheme: it should not lead to permanent transfers between countries, it should not undermine the incentives for sound fiscal policymaking at the national level, it should be consistent with the existing EU fiscal framework and it should not be an instrument for crisis management. ${ }^{2}$ The fiscal stabilisation instrument would help increase the resilience of the euro area and make future interventions by the ESM less likely.

6. In order to make the scheme acceptable and prevent permanent transfers in the long-run, moral hazard issues need to be convincingly addressed. In this respect, schemes that, like ours, use a double condition trigger can be effective in reducing moral hazard. First, since pay-outs only take place in the presence of large shocks, small fluctuations in the unemployment rate that likely reflect differences in national labour market institutions are not taken into account. Second, the support is not maintained when the unemployment rate settles down at a higher level, thus providing incentives for the country to undertake structural reforms.

7. Our paper contributes to the literature by explicitly modelling the stabilisation gains from a euro area unemployment insurance scheme when nominal interest rates are at zero. In normal times, the European Central Bank reacts to the area-wide inflation rate, so its reaction is not strong enough to fully offset an asymmetric demand shock in a given country. At the zero lower bound, the amount of stabilisation that monetary policy can deliver is reduced further, as the central bank cannot decrease the area-wide nominal interest rate below zero. With constrained monetary policy, additional fiscal integration is likely to improve macroeconomic outcomes.

8. More specifically, the present paper assesses whether a euro area unemployment insurance scheme can improve stabilisation in the presence of asymmetric shocks. We build a two-country general equilibrium model (Core and Periphery) with job market frictions along the lines of Claveres and Clemens (2017) and calibrate it to match the most important macroeconomic characteristics of the euro area. We then simulate three scenarios: one without the constraint on monetary policy and without transfers, a second one where we introduce the ZLB constraint, and finally a third where we implement both the ZLB and the transfers. Our results suggest that the unemployment insurance could mitigate about a fifth of the drop in Periphery's output caused by a negative demand shock. For a shock that would bring its GDP down by $-1.6 \%$ compared to the steady-state, at the ZLB, transfers would limit the fall in Periphery's GDP to $1.2 \%$. When the shock hits, transfers received would amount to about $1.2 \%$ of GDP. Combined with stabilisation also happening in the Core, the fall in union output would be reduced from about $-0.5 \%$ to $0.3 \%$ of euro area GDP. The effectiveness of the EUBS stems from the presence in the economy of

\footnotetext{
${ }^{2}$ See Juncker et al. (2015)
} 
households cut from financial markets, unable to save or borrow. The restrictions in accessing financial markets facing a significant share of consumers have been documented empirically (Campbell and Mankiw, 1989). In our model, the EUBS mitigates some of the crisis effects as it distributes fiscal transfers to financially constrained households, raising their current disposable income. Hence our paper provides a rationale for a fiscal capacity supporting households directly when some of them face financial constraints.

9. Additionally, we study an alternative scenario where the Periphery's government is cut off from financial markets and cannot issue debt. The negative shock is amplified, in such a situation, as the government has to increase the national tax pro-cyclically to pay out additional benefits triggered by the rise in unemployment. When activating the EUBS, transfers distributed to households uphold consumption as described above, which yields an additional benefit when the government is financially constrained. Since transfers support consumption, the recession is mitigated limiting the fiscal stress for the Periphery's government and with it the pro-cyclical tax increase. As a result, the EUBS brings additional stabilisation and alleviates the cost of market distress.

10. The rest of the paper is structured as follows: Section 2 reviews the literature on risk sharing in a monetary union, the propagation of macroeconomic shocks at the zero lower bound and on unemployment insurance. Section 3 gives a summary of the main building blocks of the model. Section 4 provides the results of model simulations and discusses the stabilisation gains from the common unemployment benefits scheme, while Section 5 presents the alternative scenario with a government losing market access. Section 6 outlines several avenues for future work and concludes.

\section{Related literature}

11. Joining a monetary union brings both benefits, such as reduction in trade costs and elimination of exchange rate risk, and costs, mainly in terms of imperfect macroeconomic stabilisation (Mundell, 1961; Kenen, 1969), while the cost-benefit assessment of a shared currency may be endogenous to the past steps toward economic integration (Frankel and Rose, 1998). Although the degree of business cycle synchronisation may increase as the track record of economic integration lengthens, the loss of independent monetary policy and nominal exchange rate flexibility is likely to be costly even after a long period of trade integration, especially if not accompanied by increased labour mobility and other risk sharing mechanisms (Bayoumi et al., 1994).

12. The literature on risk sharing usually distinguishes between public risk sharing in the form of taxes and transfers, and private risk sharing, either in the form of cross-border borrowing and lending (savings channel) or international portfolio diversification (capital market channel). The empirical studies of the risk sharing channels in federal systems show important heterogeneity among countries. For the United States, Asdrubali et al. (1996) find that between 1963 and 1990 some 75\% of the shocks to per capita state gross product are smoothed, mainly through capital and credit markets, at 39\% and $23 \%$ respectively, while fiscal transfers from the federal budget only smooth out $13 \%$ of the output shocks. In Europe, less than a half of the GDP shocks between 1966 and 1990 were smoothed, roughly one half by national budget deficits and another half by private savings (Sørensen and Yosha, 1998). Further studies of European Union countries confirmed that only $30 \%$ to $40 \%$ of GDP shocks are smoothed, mainly by social benefits (Afonso and Furceri, 2008). If anything, risk sharing in the euro area seems to have deteriorated in the aftermath of the financial crisis when more than $70 \%$ of shocks remained unsmoothed (Milano and Reichlin, 2017; ECB, 2017). On the other hand, the financial assistance instruments introduced during the European sovereign debt crisis probably increased the euro areas risk sharing capacity (Cimadomo et al., 2017).

13. The importance of public risk sharing channels, such as a common fiscal stabilisation function, is still being disputed but the arguments in support seem stronger in a monetary union. Private risk sharing 
may not be sufficient when agents insufficiently internalise the social benefits from international risk sharing, while the reality of incomplete financial markets makes the case for public risk sharing arrangement even stronger (Farhi and Werning, 2017). A similar rationale for a common fiscal instrument is the existence of spill-overs from fiscal policy in one country to other countries in a monetary union (Alcidi et al., 2016).

14. European unemployment insurance system as a cross-country temporary transfer scheme has been given increased attention (Dullien, 2014; Beblavý et al., 2017). Unemployment benefits can be effective at upholding consumption as they quickly replace lost income, reacting swiftly to the cycle, and they also target households with a high propensity to consume. In the case of asymmetric shocks, governments may become liquidity constrained or face spiking marginal borrowing costs in times of sovereign stress. Furthermore, the current system of European fiscal rules does not provide strong incentives to cut deficits or, as in case of Ireland and Spain, to sustain large surpluses in good times (Dullien, 2017). According to Allard et al. (2013), with pay-outs limited to asymmetric temporary shocks to GDP, a euro area rainy-day stabilisation fund created in 1999 could have raised the overall level of income shock smoothing to $80 \%$ (roughly, the level in Germany), at the cost of annual contributions ranging from 1.5 to $2.5 \%$ of euro area GNP. Moreover, in the case of common negative shocks, the stabilisation properties of the unemployment insurance scheme may usefully be enhanced by the ability to issue debt. An unemployment insurance scheme with borrowing capacity and annual average total payments of $0.1 \%$ of euro area GDP can provide smoothing of shocks comparable to that provided by federal budgets (Carnot et al., 2017).

15. As far as they have implications for price stability, common shocks in a monetary union would normally be stabilised by monetary policy. However, in periods when it is constrained by the zero lower bound, coordinated fiscal support may be an important part of the policy mix. Even if unconventional monetary policy provides additional accommodation, the effectiveness of unconventional measures may be limited and have undesired distributional consequences (Orphanides, 2017). Fiscal policy measures that stimulate aggregate demand, such as a temporary increase in government spending, are associated with higher multipliers in recession and at the zero lower bound (Auerbach and Gorodnichenko, 2012; Eggertsson, 2011), although the magnitude of the effect seems to be reduced when the expectations about monetary policy are more forward-looking (Swanson and Williams, 2014; Hills and Nakata, 2014).

16. In general, the unemployment scheme faces a trade-off between the provision of insurance and negative effects on incentives. In a dynamic setting, benefits should be decreasing with the length of the unemployment spell (Hopenhayn and Nicolini, 2009) and be countercyclical, as the moral hazard costs of insurance tend to be lower in times of high unemployment (Kroft and Notowidigdo, 2011). With direct relevance for our paper, the presence of the zero lower bound constraint seems to modify the labour market dynamics (Albertini and Poirier, 2015). The inflationary pressure induced by the extension of unemployment benefits in the U.S. in 2008 when nominal interest rates were close to zero, has reduced the real interest rate and partly offset the negative job search and matching effects from higher wages, resulting in reduced unemployment rate. Outside the ZLB, extending unemployment benefits has an adverse effect on unemployment.

\section{Model}

17. The model for quantitative analysis is a two-country general equilibrium model with price and labour market frictions similar to models used for analysing currency union issues (Galí and Monacelli, 2008; Engler and Voigts, 2013). Drawing on the model of Claveres and Clemens (2017), we add a fiscal capacity with the possibility of borrowing, but the specification of the different sectors is fairly standard and does not drive the results presented below. The economy consists of a two-country monetary union: we label the first country the Core and the second the Periphery. Both countries have the same structure and 
differ only by the values of their parameters. Each is inhabited by a continuum of households, some with access to financial markets and others without, by final-good and intermediate-sector firms, and by a government in the form of an unemployment agency. Monetary policy is set by a common central bank, with a zero lower-bound constraint. We add to this standard modelling a supranational entity in the form of a European unemployment insurance scheme.

18. All equations, variable definitions and the discussion of the model's calibration are given in the Appendix. The main features of the model are the following:

- Labour markets are characterized by search frictions à la Mortensen and Pissarides (1999). Searching workers and hiring firms are matched according to a constant-return-to-scale function. Firms post vacancies at a cost while all unemployed workers from the last period search for a job. The efficiency at which vacancies and unemployed searchers are converted into working matches is captured by a country-specific structural parameter. Workers and firms separate at an exogenous rate each period. We assume zero labour mobility across countries, effectively closing down this channel of international risk-sharing. This assumption can be seen as an extreme way of incorporating the low labour mobility observed in the euro area.

- Each household is made of a continuum of members that are either employed or unemployed. The former receive a wage from their supply of labour while the latter obtain unemployment benefits. Additionally, the household pays lump-sum taxes to the national government and receives transfers from the supranational scheme. A fraction of these households (called the Rule-of-Thumb households) does not have access to financial markets and only consume current disposable income. The other fraction (optimizing households) can smooth consumption inter-temporally through saving and borrowing in international financial markets. Hence, there exists some degree of private risk-sharing between the two countries, as some households can access credit markets to face idiosyncratic shocks. However, private risk-sharing is imperfect: first, because the bonds available to the households are non-contingent with respect to the state of the economy and, second, because a significant fraction of households do not have access to financial markets.

- Consumption consists of a basket of final goods produced in both the Core and the Periphery. The consumption basket represents an additional channel of risk-sharing between countries, as households can switch expenditure between the two goods in reaction to price changes. However, the risk-sharing is again imperfect, for the two goods are imperfect substitutes with a degree of home bias.

- Production is done by firms in the final good sector and intermediary firms. Firms in the final good sector bundle a variety of domestic intermediate inputs with a frictionless technology. Intermediary firms have price setting power and are subject to price adjustment costs, creating the nominal rigidities. They use labour as input for production. Finally, they optimally post a vacancy following a job creation condition, according to which the marginal cost of posting a vacancy equals the marginal benefit of having it filled.

- Wages are the outcome of a Nash bargaining process between workers and the firms, which split the surplus of a match according to a standard sharing rule depending on the worker's bargaining power. Additionally, we introduce real wage rigidity where the actual wage that the worker receives is a weighted average of the Nash-bargained and of the steady-state wage levels.

- The national government finances unemployment benefits with lump-sum taxation of households and debt issuance in financial markets. A national fiscal rule is set, including a counter-cyclical and debt stabilisation components. To assess the benefits of the supranational scheme when the 
national government faces market distress, we also study an alternative scenario where the government is cut off from financial markets.

- The supranational scheme then provides transfers directly to the households in the form of unemployment benefits according to a country-specific transfer rule and, if the funds in the scheme are insufficient to meet all the upcoming payments, it issues debt. This mechanism is similar to the borrowing made by the European Investment Bank or the European Stability Mechanism. The transfer rule implies positive transfers when the unemployment rate increases above its steadystate value, and also incorporates a stabilisation component for the debt that the scheme issues. This rule ensures that transfers are zero at the steady-state, effectively addressing the issue of permanent transfers: as long as there are no cyclical fluctuations (without shock, at the steadystate), the fund is inactive so that transfers are only temporary.

- Finally, the monetary policy follows a Taylor rule to stabilize the union inflation, but it is bound by the ZLB, as the central bank cannot decrease its nominal interest rate below zero.

19. The model calibration draws on standard parameter values from the DSGE and search and matching literature, as well as key data facts for the euro area. ${ }^{3}$ Data from 1980 to 2008 is extracted from the OECD Employment and Labour Market Statistics and the AMECO databases. Calibration choices are documented in Table 2 in the Appendix and summarized below:

- The Core comprises Austria, Belgium, Finland, France, Germany, Luxembourg and the Netherlands, while the Periphery includes Greece, Ireland, Italy, Portugal and Spain.

- Calibration implies a more sizeable, more productive Core relative to the Periphery. Labour markets are set to be more efficient and less rigid with higher employment in the Core than in the Periphery. Supply and demand shocks are programmed so that the Periphery has a higher volatility of output and consumption than the Core.

- Following the empirical literature, we assume the share of financially constrained households to be one half of the total households based on the seminal paper by Campbell and Mankiw (1989).

- Unemployment benefits are calibrated as more generous in the Core than in the Periphery. The national tax rule is set as in Engler and Voigts (2013). An increase in GDP by $1 \%$ increases the national tax by $0.3 \%$ and an increase in national debt by $1 \%$ increases the tax by $0.1 \%$. The stabilisation component of the transfer rule is set to $\phi^{\text {stab }}=1$ such that a $1 \%$ increase in unemployment compared to the steady-state implies a $1 \%$ of GDP in transfers from the scheme.

- Finally, the coefficient on debt stabilisation for the transfer rule is $\phi^{d^{e}}=\phi^{d^{e^{*}}}=0.05$, such that for each $1 \%$ increase in debt issued by the scheme, the country contribution is raised by $0.05 \%$. The debt stabilisation component of the supranational fiscal rule (increasing taxes to when debt rises) is set high enough to stabilize the supranational debt. But it is set at a lower level than that of the national rule, as we assume that repayment of the supranational debt would happen at a lower rate than the national one. These coefficients are set somewhat arbitrarily, to strike a balance between stabilisation delivered by the scheme and debt convergence in the model. But the results do not change qualitatively with the fiscal rule parameters.

\footnotetext{
${ }^{3}$ We draw on the calibration from Galí (2008); Christoffel et al. (2009); Albertini and Fairise (2013); Moyen and Stähler (2014); Guerrieri and Iacoviello (2015); Mitman and Rabinovich (2015).
} 
- This calibration allows the model to reproduce key business cycle statistics for the euro area, as reported in Table 1 in the Appendix.

\section{Simulations}

20. We simulate the behaviour of the calibrated economy in response to an asymmetric negative demand shock, implemented as an increase in a discount factor in the Periphery. Such discount factor increases have been used to mimic negative demand shocks that depress consumption and output through a shift in preferences where households suddenly value future consumption relatively more than present consumption. As a result of this shock, aggregate demand drops, pushing the economy into recession. For consumers who have access to financial markets, this negative demand shock can also be interpreted as a sudden bout of panic that makes households in the Periphery save rather than consume. In our simulations, an unexpected increase in the Periphery discount factor brings its value from 0.994 to 1.015 , consistent with a one standard deviation increase. To solve the non-linear dynamic model, we use the OccBin toolkit by Guerrieri and Iacoviello (2015). Results for the Periphery, Core and union-wide variables are reported in Figure 1, 2 and 3, respectively.

\section{Scenario 0 - Asymmetric negative demand shock without the ZLB}

21. We first analyse a hypothetical case in which the central bank is not constrained by the ZLB and can set its nominal interest rate below 0 . The corresponding results are depicted with dashed-dotted black lines in the figures.

22. In the short run, the negative demand shock originating in the Periphery depresses Periphery consumption by $1 \%$ compared to steady-state level. Output and employment decrease in response to the falling demand by $1.1 \%$ while the price level drops by $7.7 \%$, compared to steady-state. The shock results in union inflation dropping at $-0.5 \%$, to which the central bank reacts by cutting its union-wide interest rate from $1.1 \%$ to $-0.3 \%$. As it reacts to the union inflation rate, averaged over both countries, this reaction is not enough to fully offset the demand shock in the Periphery. On the contrary, the interest rate cut triggers a decrease in the real interest rate in the Core. Although the demand for Core goods drops in the Periphery, the expansionary monetary policy translates into an increase in Core consumption (of 1\%), as well as slight increases in Core output and employment (of $0.5 \%$ ).

23. As in Engler and Voigts (2013), the fact that the central bank cannot discriminate its policy between countries with its interest rate makes the demand shock asymmetric. Consumption falls in the Periphery, while it increases in the Core. Were countries not in a monetary union, each respective central bank could set country-specific interest rates to tailor monetary policy response delivering stronger stabilisation. In the end, at the scale of the union, there are small decreases in aggregate consumption and output, about $-0.1 \%$.

\section{Scenario 1 - Asymmetric negative shock with a ZLB}

24. The Periphery negative shock brings the economy to the ZLB for 5 quarters. During that time, the central bank cannot decrease the union-wide nominal interest below 0 , reducing the amount of stabilisation it can deliver. Results for this scenario are reported with solid lines.

25. As the interest rate hits the ZLB, drop in Periphery's consumption is greater $(-2.3 \%)$. Hence, the Periphery experiences a more severe recession with a bigger fall in output and employment (-1.6\%). Also, there is now stronger deflation in the Periphery. 
26. In the Core, the decrease in demand for Core goods from the Periphery is stronger than in the previous scenario, combined with a lower cut in the nominal interest rate due to the ZLB. Thus, the negative demand shock spreads to the Core countries, where the expansion is almost entirely wiped-out. Compared to the previous scenario where the interest rate cut allowed an expansion in the Core to offset the negative demand shock in the Periphery, so that at the union level the contraction would remain limited, at the ZLB the muted response of the central bank to the demand shock produces a larger recession in the Periphery, not compensated by an expansion in the Core. In the end, union's output, consumption and employment fall by more in scenario 1 than in scenario 0 .

\section{Scenario 2 - Asymmetric negative shock with a ZLB and the EUBS}

27. We now study the same negative shock in the Periphery, with the ZLB, activating the supranational unemployment benefit scheme. Results are plotted with crossed lines. The fall in employment in the Periphery triggers transfers from the European unemployment benefit scheme, which amount to $1.2 \%$ of GDP at the height of the crisis. ${ }^{4}$ These transfers from the European scheme, financed by debt issuance, uphold Periphery's consumption which now falls by $-1.9 \%$, relative to the steady state (compared to $-2.3 \%$ in scenario 1 ). Stronger consumption translates into higher output in the Periphery (falling only by $-1.2 \%$ relative to the steady state) and in the Core (increasing by $0.2 \%$ ). In the end, at the union level, the EUBS transfers help mitigate the crisis, as aggregate output and consumption fall by $-0.3 \%$ of their steady state level, compared to, respectively, $-0.5 \%$ and $-0.4 \%$ in the previous scenario.

28. The stabilisation power of the scheme strongly depends on the presence of non-Ricardian households who are cut from financial markets in the Periphery. Transfers distributed to Ricardian households are regarded as temporary and saved in expectation of future tax increases needed to consolidate the stock of debt. In other words, transfers do not change the inter-temporal revenue of optimising households, thus having no impact of their consumption (Ricardian equivalence). Indeed, in a case of no rule-of-thumb households in the Periphery (not shown), the transfers would have zero stabilisation effect, neither in the Periphery nor in the Core, and scenarios 1 and 2 would be identical. But as a significant share of households is financially constrained and financial markets remain fragmented, a fiscal capacity in the form of the EUBS mitigates the effects of the crisis by directly supporting current disposable income (in the form of unemployment benefits).

\section{The alternative scenario}

29. In the alternative scenario, we study the benefits of the EUBS when, following the negative demand shock originating in the Periphery, the Periphery's government loses access to financial markets and cannot issue debt anymore. The national government is now prevented from running its countercyclical tax policy, and the national tax must adjust to balance the budget. Note that the market distress only affects the government and not the optimizing households in the Periphery, as they still have access to financial markets. Results are depicted in Figure 4.

\section{Alternative scenario $1 b$ - Asymmetric negative shock with a ZLB and financial distress}

30. In scenario 1 in the simulation section above, the Periphery government reacts to the recession by decreasing the lump-sum tax on households by $0.5 \%$ compared to the steady-state to deliver some

\footnotetext{
${ }^{4}$ Note that when the shock hits, the Core contributes to the fund $0.2 \%$ pf GDP in negative transfers. The Core contributes to the EUBS because of the stabilisation component of the transfer rule, since there is a slight expansion and rise in employment.
} 
stabilisation at the national level. The counter-cyclical cut in national taxation translates into a rise in Periphery's government debt.

31. In scenario 1b, reported with circled lines in Figure 4, the Periphery's government loses access to financial markets. The negative shock translates into a drop in Periphery's output and a proportional rise in unemployment. Hence, more benefits have to be financed by the government, and - since debt cannot be issued - national tax has to be increased pro-cyclically. The required tax rate increase hurts the rule-ofthumb consumers, and as a result Periphery's consumption drops more than in scenario 1 . The recession is more severe, in the Periphery as well as at the union level.

\section{Alternative scenario $2 b$-Asymmetric negative shock with a ZLB, financial distress and the EUBS}

32. In scenario $2 b$, presented with starred lines in Figure 4, we activate transfers from the EUBS as in scenario 2 discussed above, but with the Periphery's government again cut off from the financial markets. The recession triggers transfers to households from the EUBS. As in scenario 2, transfers help contain the recession and the increase in unemployment. As a result, the Periphery's government faces less stringent fiscal pressure when financing an increase in benefits, and the national tax needs to increase by only $0.9 \%$ compared to steady-state (compared to $1.3 \%$ in scenario $1 \mathrm{~b}$ ). The tax increase is still pro-cyclical, but it is mitigated by the existence of the EUBS that provides further support to the income of the rule-of-thumb households. Mainly through its own debt issuance, the scheme thus partially compensates the loss of counter-cyclical fiscal policy at the national level caused by the market distress.

\section{Conclusion}

33. In order to assess potential gains from a euro area unemployment insurance scheme, we have calibrated a two-region DSGE model with supply, demand and labour market frictions, as well as a common unemployment insurance, to simulate the effects of a country-specific negative demand shock in the absence and presence of zero nominal interest rates. The introduction of a zero lower bound adds an additional layer of stabilisation losses to the standard one-size-fits-all monetary policy in a monetary union. The results from the simulation of a negative country-specific demand shock to the Periphery suggest that the existence of common unemployment insurance expands the set of policy options, in particular the mix of fiscal and monetary policy at the union level, and improves the macroeconomic stabilisation: transfers associated with the unemployment insurance scheme reduce the drop in Periphery's and union's output. We also show that the EUBS improves stabilisation further if the Periphery government is cut off from financial markets. In such situation, the EUBS alleviates the fiscal pressure by mitigating the negative effect of the rise in unemployment on public finances, hence reducing the need for a pro-cyclical tax increase induced by the loss of market access.

34. As regards future work, we see two potentially promising avenues for extending our analysis. First, one could model a non-zero trigger for reinsurance payments that would introduce a second nonlinearity. Transfers would only be paid out when unemployment increases above a given threshold, bringing a second occasionally-binding constraint to the model. This would allow us to refine further the modelling of the European unemployment scheme as one of reinsurance, which only steps in in cases of extreme shocks. Second, strategic interactions between the national and supranational institutions of government could be included. Such extension would allow us to study moral hazard effects associated with the introduction of European unemployment insurance and the impact of reforms aimed at reducing structural unemployment and improving labour market efficiency. 


\section{APPENDIX}

\section{The model}

35. We only derive equations for the Core economy and label Periphery variables or parameters with a star when needed. Variables related to the supranational layer are labelled with an $e$.

\section{Labour markets}

36. Workers flow in and out of unemployment, with labour markets being subject to search and matching frictions à la Mortensen and Pissarides (1999). As both household types, defined below, face the same probability of being hired (firms do not discriminate across household types), we do not need to specify household-specific labour market variables. In period $t$, firms post vacancies $v_{t}$ at a cost and all workers who ended the last period unemployed $u_{t-1}$ search for a job. Firms and searching workers are matched according to the following Cobb-Douglas matching function:

$$
m_{t}=\kappa^{m} u_{t-1}^{\eta} v_{t}^{1-\eta}
$$

where $0<\kappa^{m}<1$ represents the matching efficiency and $0<\eta<1$ denotes the matching elasticity with respect to unemployment. Normalizing total labour force to one, the employment rate at the end of period $t$ is equal to $n_{t}=1-u_{t}$. We assume for simplicity constant search effort, fixed number of working hours and no discouraged workers. Defining labour market tightness as $\theta_{t}=\frac{v_{t}}{u_{t-1}}$, the job finding rate for workers writes $f_{t}=\frac{m_{t}}{u_{t-1}}=\kappa^{m} \theta_{t}^{1-\eta}$ and the vacancy filling rate for firms writes $q_{t}=\frac{m_{t}}{v_{t}}=\kappa^{m} \theta_{t}^{-\eta}$.

37. Finally, workers are separated each period at the exogenous rate $0<s<1$. It follows that the number of employed workers in period $t$ is equal to those employed at the end of last period, minus those who are separated, plus the new matches for the current period. Hence the law of motion for employment writes:

$$
n_{t}=(1-s) n_{t-1}+m_{t}
$$

\section{Households}

38. The Core and the Periphery are inhabited by a mass $\omega$ and $1-\omega$ of households respectively, with $0<\omega<1$, so that the total size of the union is normalized to one.

39. Households derive utility from the consumption of a basket of domestic and foreign-produced goods with a degree of home bias. In line with the large family approach, each household is made of a continuum of members, either employed or unemployed, who pool their income to self-insure against unemployment risk. Following Galí et al. (2007), a fraction $\mu \in[0,1]$ of these households, labelled with an $r$ for "Rule-of-thumb", is cut from financial markets and cannot trade in bonds to smooth consumption. The other fraction $(1-\mu) \in[0,1]$ is made of households able to save and borrow for consumptionsmoothing purposes, labelled with an $o$ for Optimizers. Hence, there exists some private risk-sharing between the two countries, through trade in goods and bonds. Each optimizing household maximizes the following lifetime utility by choosing a sequence $\left\{c_{t}^{o}, H_{t}\right\}_{t=0}^{\infty}$ : where $c_{t}^{o}$ and $H_{t}$ denote per optimizing household consumption and holdings of nominal bonds respectively:

$$
E_{0} \sum_{t=0}^{\infty}\left(\prod_{i=0}^{t} \beta_{i}\right) \frac{\left(c_{t}^{o}\right)^{1-\gamma}}{1-\gamma}
$$


subject to the following budget constraint written in real terms:

$$
c_{t}^{o}+\frac{H_{t}}{P_{t}}=\left(1+i_{t-1}\right) \frac{H_{t-1}}{P_{t}}+w_{t} n_{t}+b u_{t}+\frac{T r_{t}}{P_{t}}+\Delta_{t}^{o}-\tau_{t}
$$

where $\beta_{i}$ represents a discount factor shock, with $\beta$ the discount factor in the steady-state, and $E_{0}$ the expectation operator at time $0 . i_{t}$ is the nominal union-wide interest rate set by the central bank, and $P_{t}$ the Core consumer price index (CPI). Among the household members, $n_{t}$ employed receive real wage $w_{t}$ from their supply of labour in the production process while $u_{t}$ unemployed at the end of $t$ receive real unemployment benefits $b$. We only consider a constant benefit policy so that real per unemployed benefits are treated as a parameter. Moreover, optimizing households receive real profits $\Delta_{t}^{o}$ as they own the firms, and they also pay lump-sum taxes $\tau_{t}$. Finally, they receive nominal transfers from the European unemployment insurance scheme, $T r_{t}$ defined below.

40. Members of Rule-of-thumb households also pool their income, but they do not have access to financial markets to insure themselves against shocks. They just consume their current disposable income, made of wage and unemployment benefits net of taxes, plus transfers. Hence, for the rule-of-thumb household consumption $c_{t}^{r}$ follows the budget constraint:

$$
c_{t}^{r}=w_{t} n_{t}+b u_{t}+\frac{T r_{t}}{P_{t}}-\tau_{t}
$$

41. Consumption consists in a basket of final Core and Periphery-produced goods, taking the form of a CES aggregate of imperfect substitutes:

$$
c_{t}^{i}=\left[\psi\left(c_{t}^{i, c}\right)^{\sigma}+(1-\psi)\left(c_{t}^{i, p}\right)^{\sigma}\right]^{\frac{1}{\sigma}}
$$

with $i \in\{o, r\}$, where $c_{t}^{i, c}$ and $c_{t}^{i, p}$ denote consumption of final Core and Periphery goods respectively by Core households, $0<\psi<1$ the degree of home bias (the relative valuation of Core products for the Core consumption basket) and $0<\sigma$ the inverse elasticity of substitution between Core and Periphery goods. Expressions for CPI as well as consumption shares in the basket read:

$$
\begin{gathered}
P_{t}=\left[\psi^{\frac{1}{1-\sigma}}\left(p_{t}^{c}\right)^{-\frac{\sigma}{1-\sigma}}+(1-\psi)^{\frac{1}{1-\sigma}}\left(p_{t}^{p}\right)^{-\frac{\sigma}{1-\sigma}}\right]^{-\frac{1-\sigma}{\sigma}} \\
\frac{c_{t}^{i, c}}{c_{t}}=\psi^{\frac{1}{1-\sigma}}\left(\frac{p_{t}^{c}}{P_{t}}\right)^{-\frac{1}{1-\sigma}} \\
\frac{c_{t}^{i, p}}{c_{t}}=(1-\psi)^{\frac{1}{1-\sigma}}\left(\frac{p_{t}^{p}}{P_{t}}\right)^{-\frac{1}{1-\sigma}}
\end{gathered}
$$

where $p_{t}^{c}$ and $p_{t}^{p}$ are the prices of the final Core and Periphery goods respectively.

At optimum, optimizing household consumption is determined by the following standard Euler equation:

$$
\lambda_{t}^{o}=\left(1+i_{t}\right) E_{t} \beta_{t+1} \frac{\lambda_{t+1}^{o}}{\Pi_{t+1}}
$$

where $\Pi_{t}=\frac{P_{t}}{P_{t-1}}$ is the CPI inflation and $\lambda_{t}^{o}=\left(c_{t}^{o}\right)^{-\gamma}$ the marginal utility for optimizing households. Similarly, marginal utility for the rule-of-thumb consumers writes $\lambda_{t}^{r}=\left(c_{t}^{r}\right)^{-\gamma}$.

Finally, we can write the marginal value of having an unemployed member turning employed (hence the marginal value of a match for the worker) in type- $i$ household as:

$$
W_{t}^{i}=w_{t}-b+E_{t} \beta_{t+1} \frac{\lambda_{t+1}^{i}}{\lambda_{t}^{i}}\left(1-s-f_{t+1}\right) W_{t+1}^{i}
$$


which is equivalent to the real wage net of unemployment benefits that this member is no longer eligible to, plus a continuation value (that same marginal value of a match discounted and corrected for $s$ in case the match separates and for $f_{t+1}$ since the same match cannot be formed next period).

\section{Firms}

42. The production side comprises an intermediate and a final good sector. A representative firm in the final good sector operates a frictionless technology by bundling a variety of intermediate products, so that final good production follows:

$$
y_{t}=\left(\int_{0}^{1} y_{t}(j)^{\frac{\varepsilon-1}{\varepsilon}} d j\right)^{\frac{\varepsilon}{\varepsilon-1}}
$$

where $y_{t}(j)$ represents the demand for intermediate input from firm $j$ in the intermediate sector, and $\varepsilon>1$ the elasticity of substitution between these intermediate inputs. All input are domestic without trade in intermediate goods. The maximisation problem of the final good firm yields the relative demand for input $j$ as well as the final good price as functions of intermediate price for Core input $p_{t}(j)$ :

$$
\begin{aligned}
& \frac{y_{t}(j)}{y_{t}}=\left(\frac{p_{t}(j)}{p_{t}^{c}}\right)^{-\varepsilon} \\
& p_{t}^{c}=\int_{0}^{1} p_{t}(j)^{1-\varepsilon} d j
\end{aligned}
$$

43. Firms in the intermediate sector use labour as input for production with the same productivity $a_{t}$ following:

$$
y_{t}(j)=a_{t} n_{t}(j)
$$

where $a_{t}$ is the country-specific aggregate technology shock, with $a_{t}=a$ in the steady-state. They face vacancy costs when they search for workers and quadratic price adjustment costs as in Rotemberg (1982), so that their profit function reads in real terms:

$$
\Delta_{t}=\frac{p_{t}(j)}{p_{t}^{c}} y_{t}(j)-w_{t} n_{t}(j)-\kappa^{v} v_{t}(j)-\Phi_{t}^{\pi}(j)
$$

where $\Phi_{t}^{\pi}(j)=\frac{\kappa^{\pi}}{2}\left(\frac{p_{t}(j)}{p_{t-1}(j)}-1\right)^{2} y_{t}(j)$ represents the real Rotemberg price costs, with $0<\kappa^{v}<1$ and $0<\kappa^{\pi}<1$ vacancy and price cost parameters. Intermediate firms choose employment, vacancies and prices so as to maximize their profits, taking into account the employment law of motion, the relative input demand function and the production function. Maximisation implies that at optimum firms post vacancies according to the following job creation condition:

$$
\frac{\kappa^{v}}{q_{t}}=a_{t} m c_{t}-w_{t}+(1-s) E_{t} \beta_{t+1} \frac{\lambda_{t+1}^{o}}{\lambda_{t}^{o}} \frac{\kappa^{v}}{q_{t+1}}
$$

where $m c_{t}$ denotes the Lagrange multiplier on the relative demand for intermediate inputs, in other words the marginal costs of the firms. According to this condition, at equilibrium, firms post vacancies until the current marginal cost of a vacancy equals its marginal benefit, comprised of the marginal product net of wage, plus a continuation value (that same cost one period ahead, discounted, provided the match does not separate). We also obtain the following New-Keynesian Phillips curve which links current inflation to expectations of future inflation and output growth:

$$
m c_{t}=\frac{\varepsilon-1}{\varepsilon}+\kappa^{\pi} \pi_{t}^{c}\left(\pi_{t}^{c}-1\right)-\kappa^{\pi} E_{t} \beta_{t+1} \frac{\lambda_{t+1}^{o}}{\lambda_{t}^{o}} \pi_{t+1}^{c}\left(\pi_{t+1}^{c}-1\right) \frac{y_{t+1}}{y_{t}}
$$


where $\pi_{t}^{c}=\frac{p_{t}^{c}}{p_{t-1}^{c}}$ is the gross rate of inflation for Core product price. Note that we have dropped the $\mathrm{j}$ subscripts after the maximisation as all intermediate firms are identical, and we can also write $n_{t}=$ $\int_{0}^{1} n_{t}(j) d j$ and $v_{t}=\int_{0}^{1} v_{t}(j) d j$. Terms in last two equations stemming from the firms maximisation problem are discounted with optimizing households marginal utility as they own the firms.

\section{Wage}

44. The equilibrium wage is determined through a Nash-bargaining process, in which workers and firms share the marginal surplus of a match depending on worker bargaining power $0<\zeta<1$. The optimal split yields the following wage schedule:

$$
\begin{aligned}
w_{t}=\zeta\left[a_{t} m c_{t}\right. & \left.+(1-s) E_{t} \beta_{t+1} \frac{\lambda_{t+1}^{o}}{\lambda_{t}^{o}} \frac{\kappa^{v}}{q_{t+1}}\right] \\
& +(1-\zeta)\left[b-E_{t} \beta_{t+1}\left(1-s-f_{t+1}\right)\left(\mu \frac{\lambda_{t+1}^{r}}{\lambda_{t}^{r}} W_{t+1}^{r}+(1-\mu) \frac{\lambda_{t+1}^{o}}{\lambda_{t}^{o}} W_{t+1}^{o}\right)\right]
\end{aligned}
$$

According to this rule, for the supply of labour, the worker obtains a share of the firms surplus from a match and a share of an outside option (unemployment benefits net of the average marginal utility of becoming employed). However, following Hall (2003), we introduce some real wage rigidity to better reproduce cyclical variations in employment and vacancies, addressing a typical issue of search and matching models known as the Shimer puzzle (Shimer, 2005). Real wage in our model follows instead a weighted average of $w_{t}$ and its steady-state value $\bar{w}$ with a wage rigidity parameter $0<v<1$ :

$$
\widetilde{w_{t}}=v w_{t}+(1-v) \bar{w}
$$

\section{Government}

45. In each country, a national government levies lump-sum taxes on households $\tau_{t}$ and issues nominal debt $D_{t}$ to finance unemployment benefits. We assume that it does not incur other expenditure than these benefits $b$, and it also rebates price adjustment costs of the firms to neutralize their business cycle effects. Hence government budget constraint follows in real terms:

$$
\tau_{t}+\frac{D_{t}}{P_{t}}=\left(1+i_{t-1}\right) \frac{D_{t-1}}{P_{t}}+u_{t} b-(1-\mu) \Phi_{t}^{\pi}
$$

The national tax rule comprises a counter-cyclical and a debt stabilisation component:

$$
\tau_{t}-\bar{\tau}=\phi^{y}\left(y_{t}-\bar{y}\right)+\phi^{d}\left(\frac{D_{t}}{P_{t}}-\frac{\bar{D}}{\bar{P}}\right)
$$

where variables with an upper bar denote steady-state levels and $\phi^{y}, \phi^{d}$ are policy parameters.

On top of national governments, a European fund organizes per-capita transfers $\left(\operatorname{Tr}_{t}, \operatorname{Tr}_{t}{ }^{*}\right)$

which can be negative. Real transfers flowing from the European fund are pinned down to changes in unemployment:

$$
\frac{T r_{t}}{P_{t} y_{t}}=\phi^{s t a b}\left(u_{t}-\bar{u}\right)-\phi^{d^{e}}\left(\frac{D_{t}^{e}}{P_{t}}-\frac{\overline{D^{e}}}{\bar{P}}\right)
$$

with $0<\phi^{s t a b}<1$ representing a policy parameter for the stabilisation delivered by the scheme. The higher the parameter, the higher the transfers when unemployment deviates from its steady-state value. When the scheme is activated, we set $\phi^{\text {stab }}=1$, so that the country receives a $1 \%$ GDP transfer for each $1 \%$ increase in its unemployment rate.. The rule above also comprises a debt stabilisation component 
scaled by $0<\phi^{d^{e}}<1$ for the debt that the scheme issues $D_{t}^{e}$, to finance these transfers. The budget constraint for the European fund writes in nominal terms:

$$
D_{t}^{e}=\left(1+i_{t-1}\right) D_{t-1}^{e}+\omega T r_{t}+(1-\omega) T r_{t}^{*}
$$

Finally, the central bank sets the interest rate according a standard Taylor rule, although bounded by the ZLB, to stabilize the average inflation rate of the union $\Pi_{t}^{u}=\omega \Pi_{t}+(1-\omega) \Pi_{t}^{*}$. We have:

$$
1+i_{t}=\left\{\begin{array}{cl}
\frac{\bar{\Pi}}{\beta}\left(\frac{\Pi_{t}^{u}}{\bar{\Pi}}\right)^{\phi^{c b}} & \text { if } i_{t}>0 \\
1 & \text { otherwise }
\end{array}\right.
$$

where $\phi^{c b}>1$ is the strength with which the central bank reacts to changes in union inflation and $\bar{\Pi}$ is its target inflation rate.

Alternative scenario In our alternative scenario where the Periphery government is cut from financial markets and cannot issue debt, the budget constraint and the tax rule equations for the Periphery are replaced by the following:

$$
\begin{gathered}
\tau_{t}^{*}=u_{t}^{*} b^{*}-\left(1-\mu^{*}\right) \Phi_{t}^{\pi^{*}} \\
D_{t}^{*}=0
\end{gathered}
$$

\section{Market clearing}

46. To close the model, we need to perform aggregation $c_{t}=\mu c_{t}^{r}+(1-\mu) c_{t}^{o}, c_{t}^{c}=\mu c_{t}^{r, c}+$ $(1-\mu) c_{t}^{o, c}, c_{t}^{p}=\mu c_{t}^{r, p}+(1-\mu) c_{t}^{o, p}$ and $\Delta_{t}=(1-\mu) \Delta_{t}^{o}$. The financial market equilibrium reads $\omega(1-\mu) H_{t}+(1-\omega)\left(1-\mu^{*}\right) H_{t}^{*}=\omega D_{t}+(1-\omega) D_{t}^{*}+D_{t}^{e}$. Finally, market clearing for the Core and Periphery goods read respectively:

$$
\begin{gathered}
\omega\left(y_{t}-\kappa^{v} v_{t}\right)=\frac{p_{t}^{c}}{P_{t}}\left[\omega c_{t}^{c}+(1-\omega) c_{t}^{c *}\right] \\
(1-\omega)\left(y_{t}{ }^{*}-\kappa^{v^{*}} v_{t}^{*}\right)=\frac{p_{t}^{p}}{P_{t}^{*}}\left[\omega c_{t}^{p}+(1-\omega) c_{t}^{p *}\right]
\end{gathered}
$$

Finally, the productivity and discount factor shocks follow an autoregressive process with mean $a$ and $\beta$ respectively, defined as such:

$$
\begin{aligned}
& \log a_{t}=\rho^{a} \log a_{t-1}+\left(1-\rho^{a}\right) \log a+\epsilon_{t}^{a} \\
& \log \beta_{t}=\rho^{\beta} \log \beta_{t-1}+\left(1-\rho^{\beta}\right) \log \beta+\epsilon_{t}^{\beta}
\end{aligned}
$$

Where $\rho^{a}$ and $\rho^{\beta}$ are persistence parameters between 0 and 1 and $\epsilon_{t}^{a}$ and $\epsilon_{t}^{\beta}$ are white noise processes with zero mean and constant variance $\sigma^{a}$ and $\sigma^{\beta}$ respectively.

\section{Calibration}

\section{Euro area calibration}

47. The relative size of the Core is set to $\omega=0.61$. The discount factor is equal to $\beta=0.994$ and the central bank target for inflation is $\bar{\Pi}=1.005$ so that the annualized steady-state interest rate settles at $4.4 \%$. The risk aversion coefficient is the same for both countries, $\gamma=\gamma^{*}=1.5$, as is the elasticity of substitution between Core and Periphery goods $\sigma=\sigma^{*}=0.904$. The degree of wage rigidity is set to 
$v=0.2$ and $v^{*}=0.15$ to reflect relatively more rigid wages in the Periphery than in the Core. We set the share of the rule-of-thumb households in the Core and the Periphery to one half, following Campbell and Mankiw (1989) as well as Engler and Voigts (2013), such that $\mu=\mu^{*}=0.5$.

48. Turning to labour market frictions, steady-state employment, job finding and vacancy filling probabilities are targeted to compute matching efficiency, vacancy cost and separation rate parameters, with $\bar{n}=0.921, \bar{f}=0.3$ and $\bar{q}=0.71$ for the Core and $\bar{n}^{*}=0.871, \bar{f}^{*}=0.29$ and $\bar{q}^{*}=0.73$ for the Periphery. This is consistent with labour markets being tighter at the steady state in the Core than in the Periphery (we have $\bar{\theta}>\bar{\theta}^{*}$ ), in the sense that the steady-state ratio of vacancies over unemployed workers is higher. Also, Core labour market are more efficient than Periphery labour market, with higher matching efficiency $\left(\kappa^{m}=0.4615\right.$ against $\left.\kappa^{m^{*}}=0.4601\right)$, lower vacancy cost as a share of GDP $\left(\kappa^{v} \bar{v} / \bar{y}=0.29 \%\right.$ against $\left.\kappa^{v^{*}} \bar{v}^{*} / \bar{y}^{*}=0.43 \%\right)$ and lower separation rate $\left(s=2.57 \%\right.$ against $\left.s^{*}=4.3 \%\right)$. The matching elasticity and the worker bargaining power are set equal in both countries, $\eta=\eta^{*}=0.5$ and $\zeta=\zeta^{*}=0.9$ respectively, so that the Hosios condition does not hold. ${ }^{5}$ Finally, unemployment benefits are a bit higher in the Core than in the Periphery, $b=0.61$ against $b^{*}=0.58$.

49. Price adjustment cost parameter, as well as elasticities of substitution between intermediate inputs are equal to standard values $\kappa^{\pi}=\kappa^{\pi *}=6$ and $\epsilon=\epsilon^{*}=10$, respectively. We normalize steadystate per capita output in the Core to $\bar{y}=1$, while it is lower in the Periphery, equal to $\bar{y}^{*}=0.85$. The relative valuation of Core goods is calibrated to $\psi=0.63$ and $\psi^{*}=0.37$ to mimic the degree of trade openness based on shares of domestic consumption to GDP. Finally, the coefficient on the Taylor rule for inflation stabilisation is set to $\phi^{c b}=1.5$. The coefficients on output and debt stabilisation for the national tax rule are equal to, respectively, $\phi^{y}=\phi^{y^{*}}=0.3$ and $\phi^{d}=\phi^{d^{*}}=0.1$ as in Engler and Voigts (2013). The stabilisation component of the transfer rule is set to $\phi^{\text {stab }}=1$ while the coefficient on debt stabilisation for the transfer rule is $\phi^{d^{e}}=\phi^{d^{e *}}=0.05$.

50. Persistence parameters for the discount factor and the productivity parameters are set to standard value of 0.9 for both countries. Then variances for these shocks are set so that productivity and discount shocks are slightly more volatile in the Periphery $\left(\sigma^{a^{*}}=0.31\right.$ and $\left.\sigma^{\beta^{*}}=0.06\right)$ than in the Core $\left(\sigma^{\beta}=\right.$ 0.25 and $\left.\sigma^{\beta}=0.04\right)$.

\section{Second moments of the model}

51. To assess the performance of the model, we rely on a comparison, presented in Table 1, between euro area data and the implied business cycle statistics of the calibrated model. Second order moments are obtained from the unconstrained version of the model without transfers, from 15000 draws including all shocks. Standard deviations are calculated from HP filtered data with smoothing parameter 1600. Data (in brackets) from 1980 to 2008 is extracted from OECD Employment and Labour Market Statistics and AMECO databases.

52. The model manages to reproduce fairly well the standard deviations of consumption, unemployment and real wage relative to output observed in the euro area Core and in the Periphery data. In particular, it captures to some extent the fluctuations of unemployment over the cycle, addressing the Shimer puzzle.

\footnotetext{
${ }^{5}$ Hence frictions in the labour market arise due to the positive between-group and the negative within- group of searching workers and firms not balancing out.
} 


\section{$\mathrm{ECO} / \mathrm{WKP}(2018) 46$}

53. Co-movement of consumption, unemployment and real wage with respect to output is also close to the data, in particular the right correlation signs are captured. However, these three variables are slightly too correlated with output compared to the data, which could be fixed with the inclusion of additional features such as capital but at the cost of model complexity.

Table 1. Second moments of the model compared to the data

Relative std. dev. to output $\sigma(x) / \sigma(y)$

Core Periphery
Correlation with output $\rho(x, y)$

\begin{tabular}{|l|c|c|c|c|}
\multicolumn{1}{c}{ Core } & Periphery & \multicolumn{2}{c}{ Core } & Periphery \\
\hline \multicolumn{1}{|c|}{ Variable $x$} & Model $[$ Data] & Model [Data] & Model [Data] & $0.99[0.88]$ \\
\hline Consumption & $0.93[0.72]$ & $0.81[0.90]$ & $0.98[0.77]$ & $-0.97[-0.73]$ \\
\hline Unemployment & $0.47[0.43]$ & $0.72[0.47]$ & $-0.92[-0.72]$ & $0.91[0.51]$ \\
\hline Real wage & $0.42[0.47]$ & $0.22[0.85]$ & $0.94[0.18]$ & $0.97]$ \\
\hline
\end{tabular}


Table 2. Calibration

\begin{tabular}{|c|c|c|c|}
\hline Households and preferences & & Core & Periphery \\
\hline Economic size & $\omega$ & 0,61 & 0,39 \\
\hline Time preference & $\beta$ & \multicolumn{2}{|c|}{0,994} \\
\hline Inverse trade elasticity & $\sigma$ & \multicolumn{2}{|c|}{0,904} \\
\hline Openness & $\psi$ & 0,63 & 0,37 \\
\hline Risk aversion & $\gamma$ & \multicolumn{2}{|c|}{1,5} \\
\hline Share of rule-of-thumb consumers & $\mu$ & \multicolumn{2}{|c|}{0,5} \\
\hline Labour markets and wage formation & & Core & Periphery \\
\hline Wage bargaining power & $\zeta$ & \multicolumn{2}{|c|}{0,9} \\
\hline Matching elasticity & $\eta$ & \multicolumn{2}{|c|}{0,5} \\
\hline Separation rate & $s$ & 0,0257 & 0,043 \\
\hline Matching efficiency & $\boldsymbol{\kappa}^{m}$ & \multicolumn{2}{|c|}{0,4583} \\
\hline Wage rigidity & $v$ & 0,2 & 0,15 \\
\hline Intermediate firms & & Core & Periphery \\
\hline Productivity & $a$ & 1,09 & 0,98 \\
\hline Elasticity of substitution between inputs & $\epsilon$ & \multicolumn{2}{|c|}{10} \\
\hline Price adjustment cost & $\boldsymbol{\kappa}^{\pi}$ & \multicolumn{2}{|c|}{6} \\
\hline Vacancy costs & $\boldsymbol{K}^{v}$ & 0,0869 & 0,0707 \\
\hline Governments & & Core & Periphery \\
\hline Unemployment benefits & $b$ & 0,61 & 0,58 \\
\hline Coefficient on output (national level) & $\phi^{y}$ & \multicolumn{2}{|c|}{0,3} \\
\hline Coefficient on debt (national level) & $\phi^{d}$ & \multicolumn{2}{|c|}{0,1} \\
\hline Taylor rule & $\phi^{a b}$ & \multicolumn{2}{|c|}{1,5} \\
\hline Inflation target & $\bar{\Pi}$ & \multicolumn{2}{|c|}{1,005} \\
\hline Stabilisation & $\phi^{s t a b}$ & \multicolumn{2}{|c|}{0 or 1} \\
\hline Coefficient on debt (European level) & $\phi^{d^{\theta}}$ & \multicolumn{2}{|c|}{0,05} \\
\hline Shocks & & Core & Periphery \\
\hline Productivity shock persistence & $\rho^{\bar{a}}$ & \multicolumn{2}{|c|}{0,9} \\
\hline Productivity shock variance & $\sigma^{a}$ & 0,25 & 0,31 \\
\hline Demand shock persistence & $\rho^{\beta}$ & \multicolumn{2}{|c|}{0,9} \\
\hline Demand shock variance & $\sigma^{\beta}$ & 0,04 & 0,06 \\
\hline
\end{tabular}


Figure 1. Periphery variables
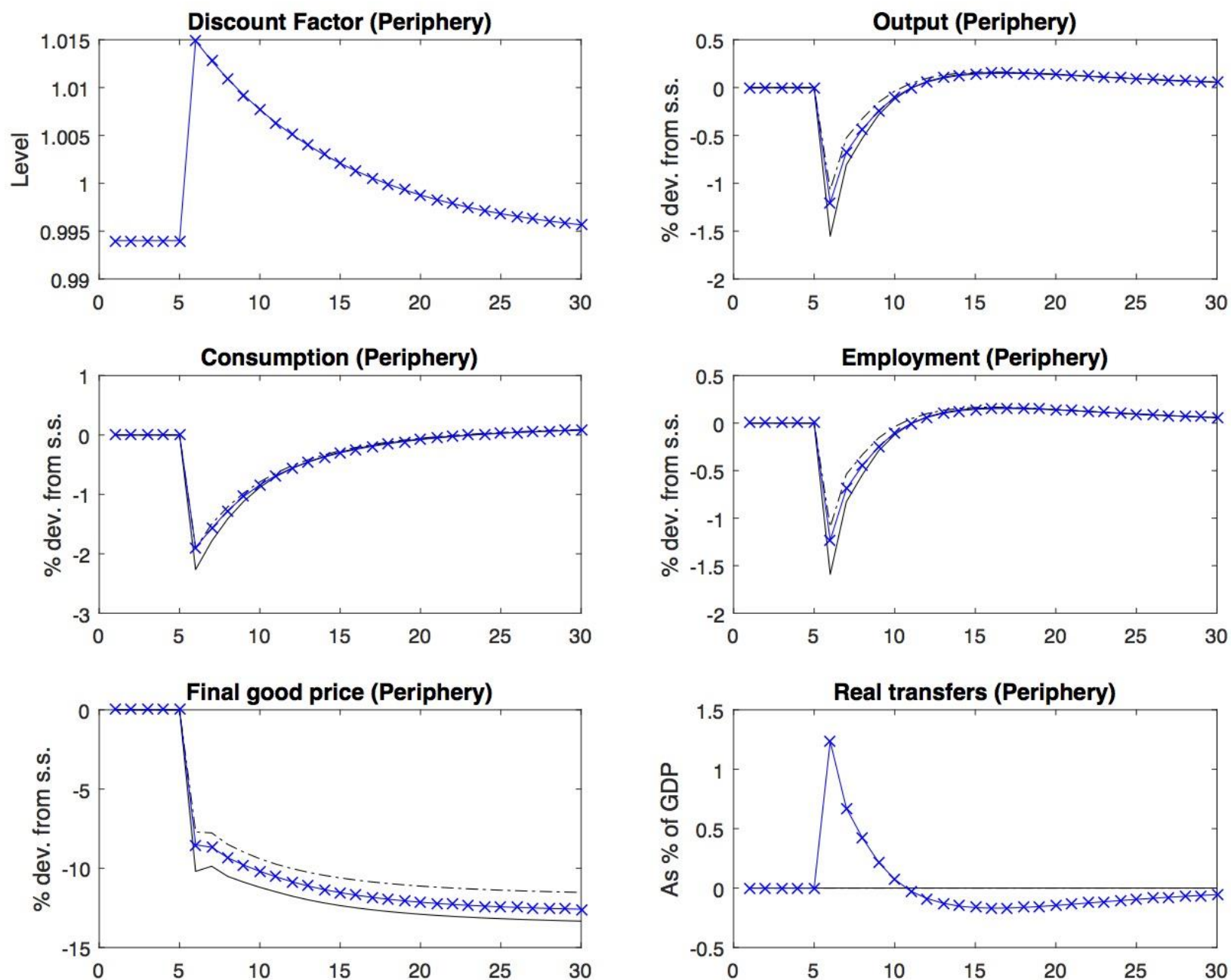

Note: Periods are quarters. Dashed lines: shock without ZLB constraint, no EUBS (scenario 0); solid lines: shock with ZLB constraint, no EUBS (scenario 1); crossed lines: shock with ZLB constraint, with EUBS (scenario 2). 
Figure 2. Core variables
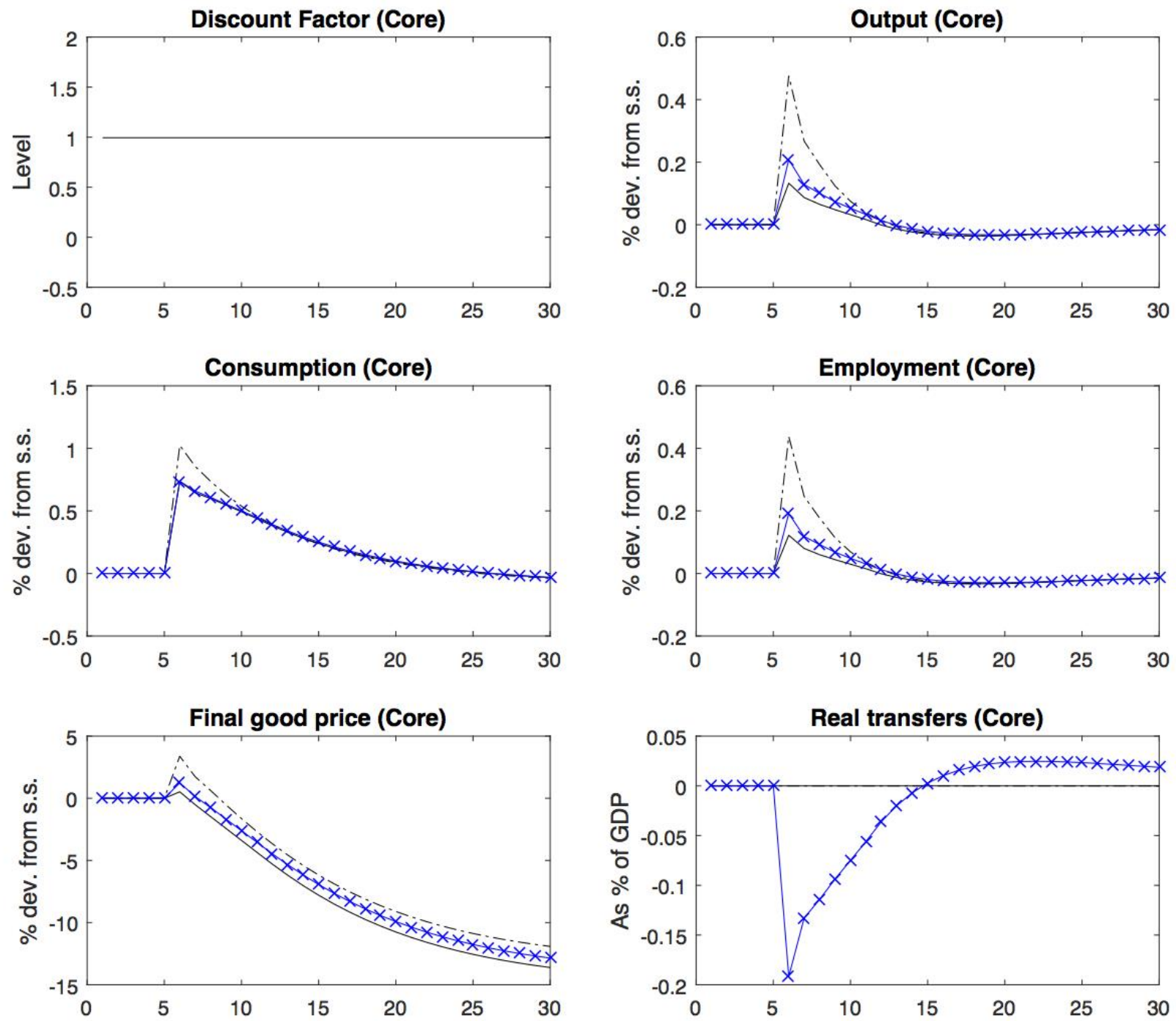

Note: Periods are quarters. Dashed lines: shock without ZLB constraint, no EUBS (scenario 0); solid lines: shock with ZLB constraint, no EUBS (scenario 1); crossed lines: shock with ZLB constraint, with EUBS (scenario 2). 
Figure 3. Union variables
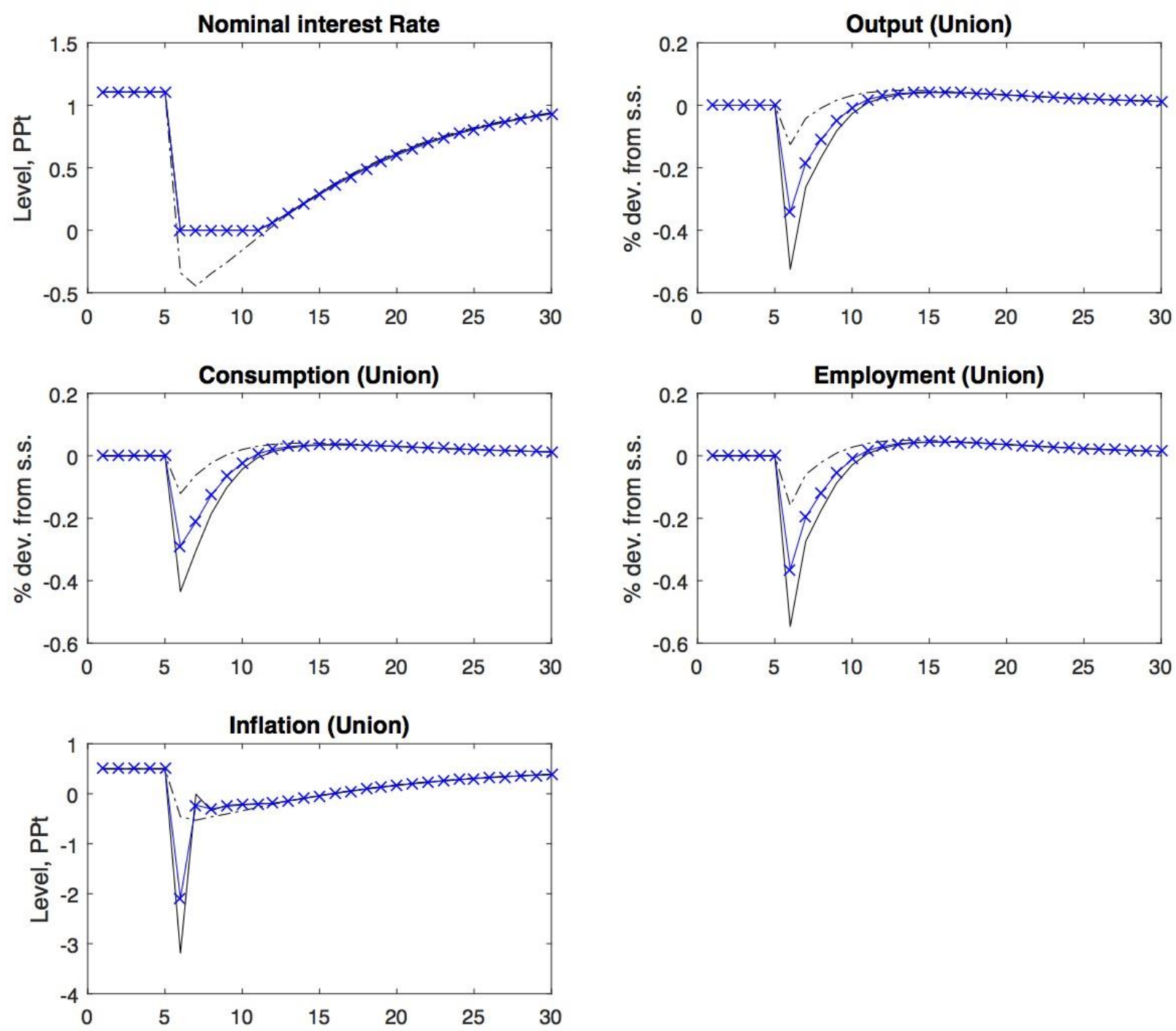

Note: Periods are quarters. Dashed lines: shock without ZLB constraint, no EUBS (scenario 0); solid lines: shock with ZLB constraint, no EUBS (scenario 1); crossed lines: shock with ZLB constraint, with EUBS (scenario 2). 
Figure 4. Alternative scenario
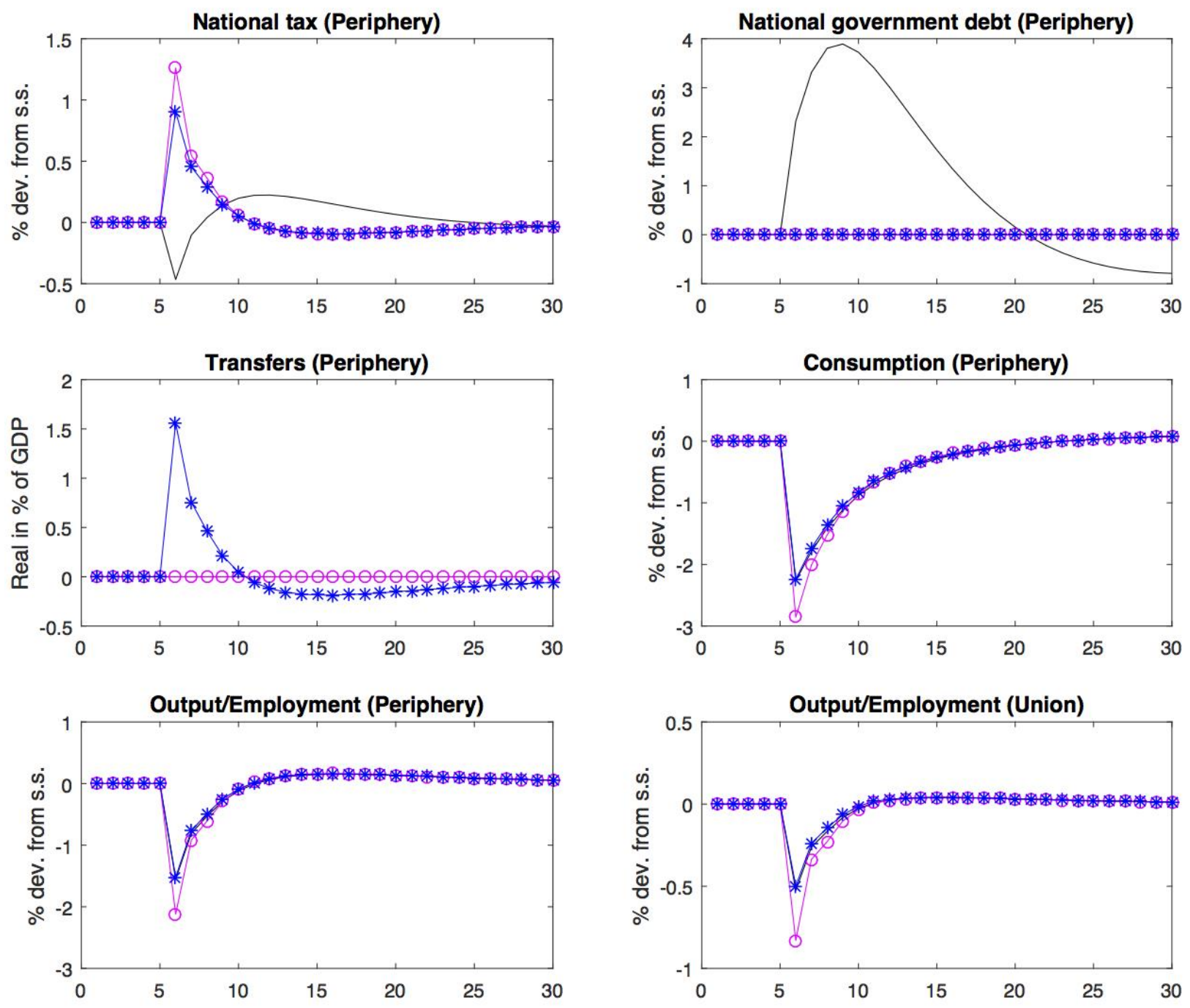

Note: Periods are quarters. Solid lines: shock with ZLB constraint, no EUBS (scenario 1); Rounded lines: shock with ZLB constraint and market distress, no EUBS (scenario 1b); Starred lines: shock with ZLB constraint, market distress and the EUBS (scenario 2b). 


\section{BIBLIOGRAPHY}

Afonso, A. and D. Furceri (2008), "EMU enlargement, stabilisation costs and insurance mechanisms", Journal of International Money and Finance, Vol. 27, No. 2, pp. 169-187.

Albertini, J., and Fairise, X. (2013). Search frictions, real wage rigidities and the optimal design of unemployment insurance. Journal of Economic Dynamics and Control, Vol. 37, No. 9, pp. 17961813.

Albertini, J. and A. Poirier (2015), "Unemployment benefits extensions at the zero lower bound", Review of Economic Dynamics, Vol. 18, No. 4, pp. 733-751.

Alcidi, C., Määttänen, N. and G. Thirion (2015), “Cross-country spillover effects and fiscal policy coordination in EMU", FIRSTRUN, http://www.firstrun.eu/files/2015/12/D1.1_literature_review.pdf.

Allard, C. et al. (2013), "Towards a fiscal union for the euro area”, IMF Staff Discussion Note SDN/13/09, International Monetary Fund, Washington, D.C.

Asdrubali, P., Sørensen, B. and O. Yosha (1996), "Channels of interstate risk sharing: United States 19631990”, Quarterly Journal of Economics, Vol. 111, No. 4, pp. 1081-1110.

Auerbach, A. and Y. Gorodnichenko (2011), "Fiscal multipliers in recession and expansion", NBER Working Paper No. 17447, National Bureau of Economic Research, Cambridge, MA.

Bayoumi, T. and B. Eichengreen (1994), "One money or many? Analyzing the prospects for monetary unification in various parts of the world", Princeton Studies in International Finance, No. 76, Princeton University, Princeton, New Jersey.

Beblavý, M. and K. Lenaerts (2017), "Feasibility and added value of a European Unemployment Benefits Scheme", Centre for European Policy Studies, Brussels.

Campbell J.Y. and N. G. Mankiw (1989), Consumption, income, and interest rates: Reinterpret- ing the time series evidence, NBER macroeconomics annual, 4:185-216.

Carnot, N., Kizior, M. and G. Mourre (2017), "Fiscal stabilisation in the euro area: A simulation exercise", CEB Working Paper No. 17/025, Université Libre de Bruxelles - Solvay Brussels School of Economics and Management, Brussels.

Christoffel, K., Kuester, K., and Linzert, T. (2009), The role of labor markets for euro area monetary policy. European Economic Review, 53(8), 908-936.

Cimadomo, J., Furtuna, O. and M. Guilidori (2017), "Private and public risk sharing in the euro area", Tinbergen Institute Discussion Paper 2017-064/VI, Tinbergen Institute, Amsterdam.

Claveres, G. and M. Clemens (2017), “European Unemployment Insurance”, mimeo.

Dullien, S. (2014), A European Unemployment Benefit Scheme: How to provide more stability in the euro zone, Verlag Bertelsmann Stiftung, Gütersloh. 
Dullien, S. (2017), "Ten lessons from a decade of debating an EUBS: Robust findings, popular myths and remaining dilemmas", Intereconomics, Vol. 52, No. 3, pp. 159-164.

ECB (2017), Financial Integration in Europe 2017, European Central Bank, Frankfurt am Main.

Eggertsson, G. (2011), "What fiscal policy is effective at zero interest rates?", NBER Macroeconomics Annual 2010,Vol. 25, pp. 59-112.

Engler, P. and S. Voigts (2013), “A transfer mechanism for a monetary union”, Discussion Paper No. 2013-013, Humboldt University, Berlin.

Fahri, E. and I. Werning (2012), "Fiscal Unions”, NBER Working Paper No. 18280, National Bureau of Economic Research, Cambridge, MA.

Faia, E. (2008), “Optimal monetary policy rules with labour market frictions”, Journal of Economic dynamics and control, 32(5), 1600-1621.

Frankel and Rose (1998), "The endogeneity of the optimum currency area criteria", Economic Journal, Vol. 108, No. 449, pp. 1009-1025.

Furceri, D. and A. Zdzienicka (2015), "The euro area crisis: Need for a supranational fiscal risk sharing mechanism?", Open Economies Review, Vol. 26, No. 4, pp. 683-710.

Galí J. (2008), Monetary policy, inflation, and the business cycle: an introduction to the new Keynesian framework and its applications, Princeton University Press.

Galí, J., López-Salido, J. D., and J. Vallés (2007), "Understanding the effects of government spending on consumption", Journal of the European Economic Association, 5(1), 227-270.

Gali, J., and Monacelli, T. (2008), "Optimal monetary and fiscal policy in a currency union", Journal of international economics, 76(1), 116-132.

Guerrieri, L. and M. Iacoviello (2015), "OccBin: A toolkit for solving dynamic models with occasionally binding constraints easily", Journal of Monetary Economics, Vol. 70, No. 1, pp.22-38.

Hall, R. E. (2003), “Wage determination and employment fluctuations”, NBER Working Paper No. 9967, National Bureau of Economic Research, Cambridge, MA.

Hills, T. and T. Nakata (2014), "Fiscal multipliers at the zero lower bound: the role of policy inertia", mimeo. https://www.federalreserve.gov/econresdata/feds/2014/files/2014107pap.pdf

Hopenhayn, H. A. and J. P. Nicolini (2009), "Optimal unemployment insurance and employment history", Review of Economic Studies, Vol. 76, No. 3, pp. 1049-1070.

Juncker, J.-C. et al. (2015), “Completing Europe's Economic and Monetary Union”, European Commission, Brussels.

Kennen, P. (1969), "The theory of optimum currency areas: An eclectic view", in: R. Mundell and A. Swoboda (eds.), Monetary problems in the International Economy, pp. 41-60, University of Chicago Press, Chicago. 
Kroft K. and M. J. Notowidigdo (2011), "Should unemployment insurance vary with the unemployment rate? Theory and evidence", NBER Working Paper No. 17173, National Bureau of Economic Research, Cambridge, MA.

MacDougall et al. (1977), Report of the Study Group on the Role of Public Finance in European Integration, European Commission, Brussels.

Milano, V. and P. Reichlin (2017), "Risk sharing across the US and EMU: The role of public institutions", VoxEU. http://voxeu.org/article/risk-sharing-across-us-and-eurozone

Mitman, K., and S. Rabinovich, (2015), "Optimal unemployment insurance in an equilibrium businesscycle model”, Journal of Monetary Economics, Vol. 71, No., pp. 99-118.

Mortensen, D. T. and C. A. Pissarides (1999), "New developments in models of search in the labour market", Chapter in Handbook of labor economics, 3, pp. 2567-2627.

Moyen, S. and N. Stähler (2014), "Unemployment insurance and the business cycle: should benefit entitlement duration react to the cycle?", Macroeconomic Dynamics, Vol. 18, No. 3, pp. 497-525.

Mundell, R. (1961), “A theory of optimum currency areas”, American Economic Review, Vol. 51, No. 4, pp. 657-665.

Orphanides, A. (2017), "The fiscal-monetary policy mix in the euro area: Challenges at the zero lower bound", Discussion Paper 60, European Commission, Brussels.

Rachel, L. and T. D. Smith (2017), “Are low real interest rates here to stay?”, International Journal of Central Banking, Volume 13, No. 3, pp. 1-42.

Rotemberg, J. J. (1982), "Monopolistic price adjustment and aggregate output", Review of Economic Studies, Vol. 49, No. 4, pp. 517-531.

Shimer, R. (2005), "The cyclical behavior of equilibrium unemployment and vacancies", American Economic Review, Vol. 95, No. 1, pp. 25-49.

Sørensen, B. and O. Yosha (1998), "International risk sharing and European monetary unification", Journal of International Economics, Vol. 45, No. 2, pp. 211-238.

Swansson, E. and J. Williams (2014), "Measuring the effect of the zero lower bound on medium- and longer-term interest rates", American Economic Review, Vol. 104, No. 10, pp. 3154-3185. 